\title{
Quality of 'Hayward' Kiwifruit in Prolonged Cold Storage as Affected by the Stage of Maturity at Harvest
}

\author{
Tal Goldberg ${ }^{1,2, *}$, Harel Agra ${ }^{2,3}$ and Ruth Ben-Arie ${ }^{2}$ \\ 1 Department of Food Sciences, Faculty of Sciences and Technology, Tel-Hai College, M.P. Upper Galilee, \\ Qiryat Shemona 1221000, Israel \\ 2 Fruit Storage Research Laboratory MIGAL, Galilee Technology Center, P.O. Box 831, Kiryat-Shmona 1101600, \\ Israel; hagra@staff.haifa.ac.il (H.A.); ruth.benarie@gmail.com (R.B.-A.) \\ 3 The Kadas Green Roofs Ecology Center, University of Haifa, Haifa 3498838, Israel \\ * Correspondence: taligold@telhai.ac.il; Tel.: +972-507214708
}

Citation: Goldberg, T.; Agra, H.; Ben-Arie, R. Quality of 'Hayward' Kiwifruit in Prolonged Cold Storage as Affected by the Stage of Maturity at Harvest. Horticulturae 2021, 7, 358. https://doi.org/10.3390/ horticulturae7100358

Academic Editor: Maria Dulce Carlos Antunes

Received: 24 July 2021

Accepted: 15 September 2021

Published: 03 October 2021

Publisher's Note: MDPI stays neutral with regard to jurisdictional claims in published maps and institutional affiliations.

Copyright: (C) 2021 by the authors. Licensee MDPI, Basel, Switzerland. This article is an open access article distributed under the terms and conditions of the Creative Commons Attribution (CC BY) license (https:// creativecommons.org/licenses/by/ $4.0 /)$.

\begin{abstract}
The effect of 'Hayward' kiwifruit maturity at harvest on fruit quality during long-term storage at $-0.5{ }^{\circ} \mathrm{C}$ was evaluated by harvesting the fruit several times, at different stages of maturity. The progress of maturation on the vine was monitored weekly from 136 DAFB (days after full bloom). Fruit were harvested for storage at three points and stored for 3-6 months in regular air (RA), or for 6-10 months in a controlled atmosphere (CA), with or without prestorage exposure to 1-methylcyclopropene (1-MCP). The softening rate under both storage regimes decreased with the advance in fruit maturation on the vine, as indicated by increasing soluble solids content (SSC), and declining firmness. As a result, the fruit from the first harvest (152 DAFB), which were the firmest at harvest, were the softest at the end of both storage regimes. Delaying harvest also decelerated the decline in acidity during storage, so that fruit picked last maintained the highest titratable acidity (TA) upon removal from storage. The overall fruit quality after shelf life, following prolonged storage in either RA or CA, was improved by delaying harvest to late November (ca. 200 DAFB). The harvest criteria for fruit with the best storage potential were dry matter (DM) > 17\%, SSC > 7\%, TA 2.0-2.6\%, with more than $40 \%$ of the DM non soluble. From a commercial aspect the rule should therefore be 'Last in, last out' (LILO).
\end{abstract}

Keywords: acidity; harvest index; firmness; ripening; postharvest; softening; soluble solids

\section{Introduction}

Postharvest quality of 'Hayward' kiwifruit (Actinidia deliciosa) is largely determined by the stage of maturity at harvest [1]. Hence, an important preharvest strategy is to monitor fruit development and to assess physiological maturity at harvest. The ability to assess the optimal time for harvest in accordance with the desired duration of storage is of considerable commercial value [2]. Physiological maturity is defined as the stage at which the fruit is capable of achieving full ripeness after harvest, i.e., suitability for consumption or processing. As kiwifruit is a climacteric fruit, it can be harvested when physiologically mature but unripe [3]. When picked at the appropriate stage of maturity, kiwifruit store and ripen satisfactorily, whereas if harvested too early, prior to reaching physiological maturity, this is not so, or if harvested when almost ripe, they soften rapidly during storage [4]. Early harvested kiwifruit of three cvs. were recently shown to have a better storage potential than late harvested fruit [5].

The commonly used index for harvesting mature kiwifruit is the level of SSC. Studies carried out in California [6] and in New Zealand [7] have defined 6.5\% and 6.2\% SSC, respectively, as the minimum level at harvest enabling 'Hayward' kiwifruit to ripen to good organoleptic quality after cold storage for three to six months. This level is presumably related to the onset of starch hydrolysis and soluble sugar accumulation in kiwifruit [8]. Introduced about 40 years ago, this is only a minimum index, and more mature fruit 
(e.g., SSC 8-10\%) have been recommended for CA storage [9]. A high SSC at harvest, obtained late in the season, increases consumer acceptance when the fruit becomes edible [10], yet the endpoint for harvest of fruit intended for storage has not been clearly defined, especially with regard to extending the storage duration by means of $\mathrm{CA}$ and/or treatment with 1-MCP. Another advantage expected from a high SSC at harvest is an increased resistance to chilling injury [11,12]. However, in the northern hemisphere, delaying harvest exposes the fruit to the risk of frost [13].

The organic acid content of the fruit flesh is affected by environmental and cultivation practices (e.g., temperature, light intensity, cultivar, rootstock, mineral nutrition, water availability, and fruit load/pruning) [14]. During storage, there is a decrease in TA and a rise in $\mathrm{pH}$ [15], and the decline in acidity in kiwifruit is related to fruit softening [16]. Kiwifruit flavor is highly dependent on the balance between soluble sugars and nonvolatile organic acids [17].

The DM content of kiwifruit, mainly composed of soluble solids such as sugars and insoluble solids such as starch and carbohydrate, is highly correlated with the increase in soluble solids as fruit mature. Most kiwifruit have an at-harvest DM content in the range of $14-17 \%$ [18], remaining reasonably constant during postharvest ripening with only small losses due to respiration [19]. A higher DM content at harvest resulted in better consumer evaluation compared to a low DM content [18]. It was also associated with a higher organic acid content and the retention of greater flesh firmness during storage [14].

During storage, flesh firmness significantly decreases and the fruit becomes edible when firmness is below $25 \mathrm{~N}$ [20]. Fruit softening is accompanied by increased susceptibility to damage [14], and from a commercial point of view, the most valuable fruit is that which has a slow rate of softening. CA storage $\left(2 \% \mathrm{O}_{2}+5 \% \mathrm{CO}_{2}\right)$ retarded softening of kiwifruit at $0{ }^{\circ} \mathrm{C}[21,22]$ and prestorage treatment with $1-\mathrm{MCP}$, an inhibitor of ethylene perception, prolonged storage and shelf life by reducing the fruit softening rate [23]. However, some reports have shown that late harvested kiwifruit maintain their flesh firmness throughout RA storage better than early harvested fruit $[24,25]$. Leaving the fruit on the vine for too long, allows softening to progress too far and thereby reduces subsequent storage life [26]. In addition, for the yellow-fleshed 'Hort16A' kiwifruit it was found that the incidence of CI increased with storage time, but was lower in later harvested fruit for any given storage period [27]. The effects of CA storage and 1-MCP treatment on late-harvested kiwifruit have not been studied systematically. Therefore, in this study, we investigated changes in the physicochemical and quality characteristics of late-harvested kiwifruit stored for up to six months in RA or up to 10 months in CA, with and without 1-MCP treatment prior to storage.

\section{Materials and Methods}

Experiments were conducted during 2017 and 2018 in a 15-year-old commercial 'Hayward' kiwifruit orchard located in the Upper Galilee, Israel. In 2017, bloom began on 9 May and in 2018, 10 days earlier, on 29 April. The on-vine maturation of 'Hayward' kiwifruit in 2017 was assessed weekly from 24 September (136 DAFB) on five replicates of 30 uniform fruit sampled from the same vines, each weighing 100-120 g, and monitored destructively for fruit firmness, DM and SSC.

The fruit for storage were harvested in 2017 at 152 DAFB (8 October), 178 DAFB (5 November), and 192 DAFB (19 November) and in 2018, at 192 DAFB (17 November) and 202 DAFB (27 November). All fruit were immediately transported to the laboratory, where they were dipped for $20 \mathrm{~s}$ in $0.1 \%$ Scholar (Syngenta Inc., Wilmington, NC, USA) and cured at ambient temperature for $48 \mathrm{~h}$, to prevent decay development, simulating local commercial practice. In 2017, fruit were stored at $-0.5^{\circ} \mathrm{C}$ in RA. In 2018, half the fruit were treated with $0.6 \mu \mathrm{L} \mathrm{L}^{-1} 1-\mathrm{MCP}$ (AgroFresh Inc., Philadelphia, PA, USA), for $24 \mathrm{~h}$ at $0{ }^{\circ} \mathrm{C}$ and half served as the untreated control. After 1-MCP application, all fruit were stored at $-0.5{ }^{\circ} \mathrm{C}$ in $\mathrm{CA}$ at $2 \% \mathrm{O}_{2}, 825 \% \mathrm{CO}_{2}$, and $93 \% \mathrm{~N}_{2}$. In all storage cabinets, the ethylene level was monitored throughout storage and remained below $2 \mathrm{nlL}^{-1}$. Each treatment 
was applied to five replicates of 20 fruit for each storage duration. Fruit evaluation was conducted monthly upon removal from storage after three-six months in 2017 and after six, eight, and 10 months in 2018. Overnight equilibration at $20^{\circ} \mathrm{C}$ preceded destructive measurements on half of the fruit in each replicate. The quality of the remainder was assessed following shelf life $\left(20^{\circ} \mathrm{C}, 65 \%\right.$ relative humidity) after six (2017) or seven (2018) days.

DM was measured by drying two $\mathrm{mm}$ thick equatorial slices at $65^{\circ} \mathrm{C}$ to a constant weight (approximately $24 \mathrm{~h}$ ). Firmness was measured by peeling the skin from the opposite sides of each fruit at the equatorial zone and the outer pericarp firmness was measured using a fruit texture analyzer (GUSS Ltd, Western Cape, South Africa) fitted with an eight $\mathrm{mm}$ plunger. Fruit juice was extracted from firm fruit with an electric juicing machine and from soft fruit by hand. SSC was measured using a digital refractometer (ATAGO Ltd., Bellevue, WA, USA) and was expressed as Brix (\%). TA was assayed by titration of juice diluted in water (1:20) with $0.1 \mathrm{M} \mathrm{NaOH}$ to $\mathrm{pH} 8.1$ using an automatic titrator (SCHOTT Ltd., Mainz, Germany). The results were calculated as citric acid and expressed as $\mathrm{g} \times 100 \mathrm{~g}^{-1} 95(\%)$ of fresh weight. The $\mathrm{pH}$ of the fruit juice was measured with the same device. The nonsoluble fraction, expressed as percentage of DM (\%), was calculated by subtracting the SSC content from the DM content and dividing by the DM content:

$$
\text { Non soluble dry matter }(\mathrm{NSDM})(\%)=\frac{(\mathrm{DM}-\mathrm{SSC}) \times 100}{\mathrm{DM}}
$$

Organoleptic tests were performed at the end of shelf life after six months of RA storage in 2017 and after eight months of CA storage in 2018. Tests were conducted with trained teams. In 2017 there were 14 panelists, each tasting two samples: 172 and 192 DAFB. In 2018, 13 panelists randomly tasted two of 23 samples: 14 samples without 1-MCP (seven 172 DAFB and seven 192 DAFB) and nine samples stored after exposure to 1-MCP (five 172 DAFB and four 192 DAFB). The panelists evaluated the samples for flavor, off-flavor, sweetness, and sourness on a scale of $1-10$. We calculated an 'overall taste index':

$$
\frac{(\text { flavor }- \text { off flavor }) \times \text { sweetness }}{\text { sourness }}
$$

Fruit of the 152 DAFB harvest in 2017 was not suitable for consumption.

Statistical analyses were performed using IBM SPSS statistics 23 (IBM Corp, Armonk, NY, USA). Differences between DAFBs in ripening indices were tested using one-way ANOVA and Duncan posthoc test. Differences between DAFBs in overall taste index after shelf life were tested, using paired-samples $t$-test for 2017 and random-samples $t$-test for 2018.

\section{Results}

\subsection{Maturation in the Orchard}

Fruit dry weight increased at a constant rate from 136 DAFB at the end of September to 198 DAFB at the end of November (Figure 1A), simultaneously with an almost linear increase in $\sim 3.6 \%$ in SSC (Figure 1B). NSDM, consisting mainly of structural carbohydrates and starch, began to decrease at about 160 DAFB and thereafter diminished constantly as ripening progressed, from about $66 \%$ to below $50 \%$ at the end of November (Figure 1C). It is a mirror image of the SSC content, indicating that starch had ceased to accumulate. During the same period, fruit firmness decreased initially at a rate of $0.1 \mathrm{~N} \mathrm{day}^{-1}$ up to $175 \mathrm{DAFB}$, thereafter increasing to $0.5 \mathrm{~N} \mathrm{day}^{-1}$ (Figure 1D). 


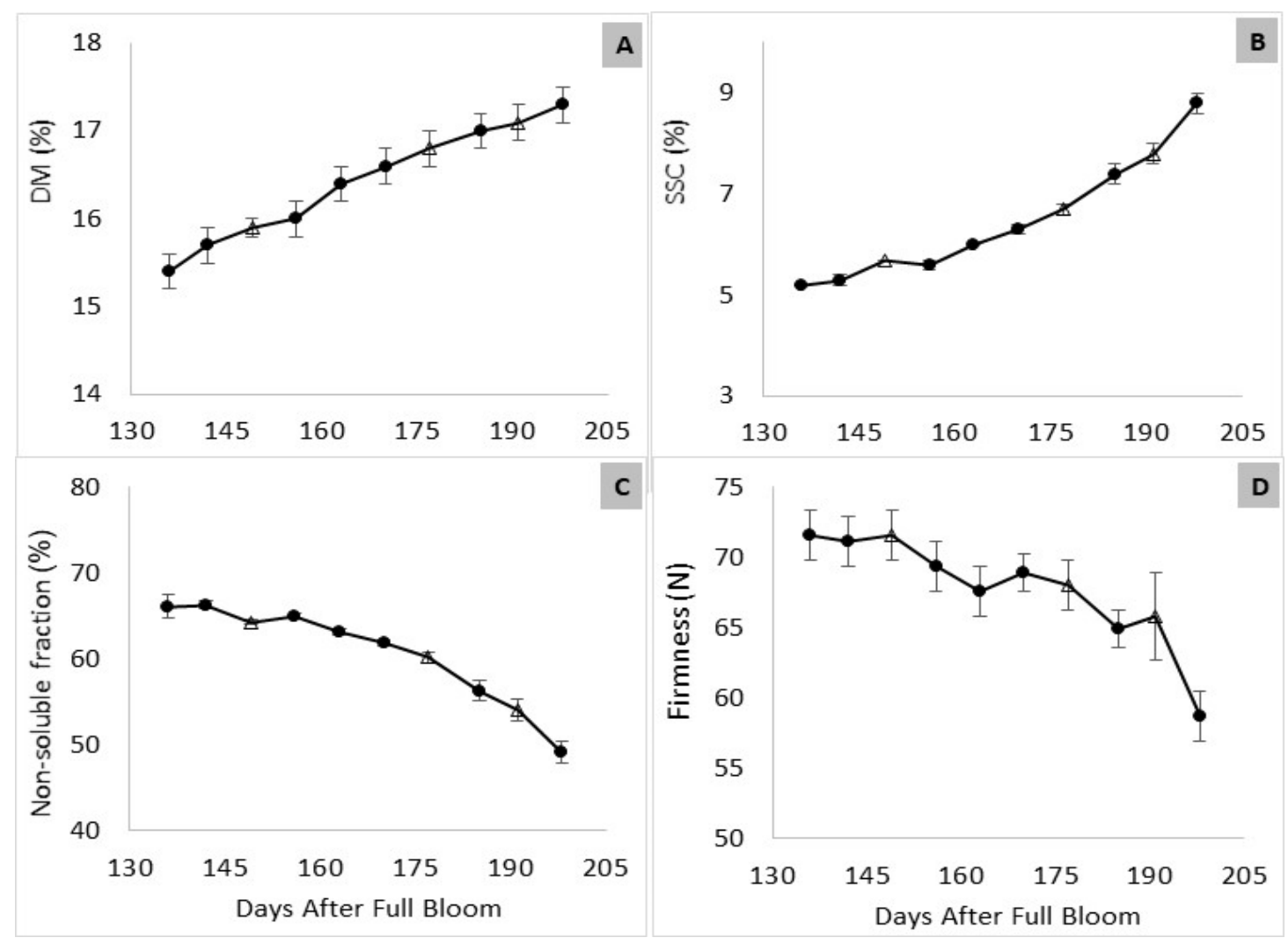

Figure 1. Progress of maturity indices during kiwifruit ripening: DM (A), SSC (B), NSDM (C), firmness (D), 2017. Harvests for fruit storage are marked by triangles.

\subsection{Fruit Maturity at Harvest}

The maturity indices of kiwifruit harvested for storage, three times in 2017 and twice in 2018, are shown in Table 1. In 2017, DM content, SSC, and the SSC/TA ratio increased significantly with each harvest, while flesh firmness decreased. During this period, there was an increase in TA content from $2.2 \%$ at 152 DAFB to $2.6 \%$ at 192 DAFB and a tendency for $\mathrm{pH}$ to decline.

Table 1. Ripening indices (mean \pm SE, $n=5$ ) of kiwifruit harvested for storage in 2017 and 2018 .

\begin{tabular}{ccccccc}
\hline Harvest & DM (\%) & SSC (\%) & FTA (N) & TA (\%) & pH & SSC/TA \\
\hline 152 DAFB & $15.9 \pm 0.1 \mathrm{~B}$ & $5.7 \pm 0.1 \mathrm{C}$ & $71.6 \pm 1.3 \mathrm{~A}$ & $2.0 \pm 0.0 \mathrm{C}$ & $3.3 \pm 0.01 \mathrm{~A}$ & $2.9 \pm 0.1 \mathrm{AB}$ \\
\hline $178 \mathrm{DAFB}$ & $16.8 \pm 0.2 \mathrm{~A}$ & $6.7 \pm 0.1 \mathrm{~B}$ & $68.1 \pm 1.8 \mathrm{AB}$ & $2.4 \pm 0.0 \mathrm{~B}$ & $3.0 \pm 0.01 \mathrm{C}$ & $2.7 \pm 0.1 \mathrm{~B}$ \\
\hline $192 \mathrm{DAFB}$ & $17.1 \pm 0.2 \mathrm{~A}$ & $7.8 \pm 0.1 \mathrm{~A}$ & $65.8 \pm 1.8 \mathrm{~B}$ & $2.6 \pm 0.0 \mathrm{~A}$ & $3.2 \pm 0.04 \mathrm{~B}$ & $3.1 \pm 0.1 \mathrm{~A}$ \\
\hline & & 2018 & & $3.3 \pm 0.01$ & $3.5 \pm 0.1 \mathrm{~B}$ \\
\hline $192 \mathrm{DAFB}$ & $17.7 \pm 0.2 \mathrm{~A}$ & $8.1 \pm 0.1 \mathrm{~B}$ & $65.4 \pm 1.8 \mathrm{~A}$ & $2.3 \pm 0.0 \mathrm{~A}$ & $3.3 \pm 0.02$ & $5.0 \pm 0.1 \mathrm{~A}$ \\
\hline $202 \mathrm{DAFB}$ & $16.9 \pm 0.2 \mathrm{~B}$ & $10.7 \pm 0.3 \mathrm{~A}$ & $56.0 \pm 3.1 \mathrm{~B}$ & $2.1 \pm 0.0 \mathrm{~B}$ & 3.3 \\
\hline
\end{tabular}

The letters A-C represent significant differences between harvests $(p<0.05)$, separately for each season.

Maturity indices for the first harvest in 2018 were similar to those of the third harvest in 2017, both occurring at 192 DAFB. At the late harvest in 2018, SSC increased whereas DM, flesh firmness, and TA content decreased. TA content at all harvests, during both seasons, was above $2 \%$. 


\subsection{Changes in Fruit Composition during Storage \\ 3.3.1. RA Storage}

Although fruit of the last harvest was the softest at harvest, its rate of softening during storage was the slowest and, after six months' storage in RA, it was the firmest. In addition, despite no significant difference in the firmness of fruit from the first two harvests, that of the second harvest was significantly firmer after three months' storage but without any difference from four to six months (Figure 2A).

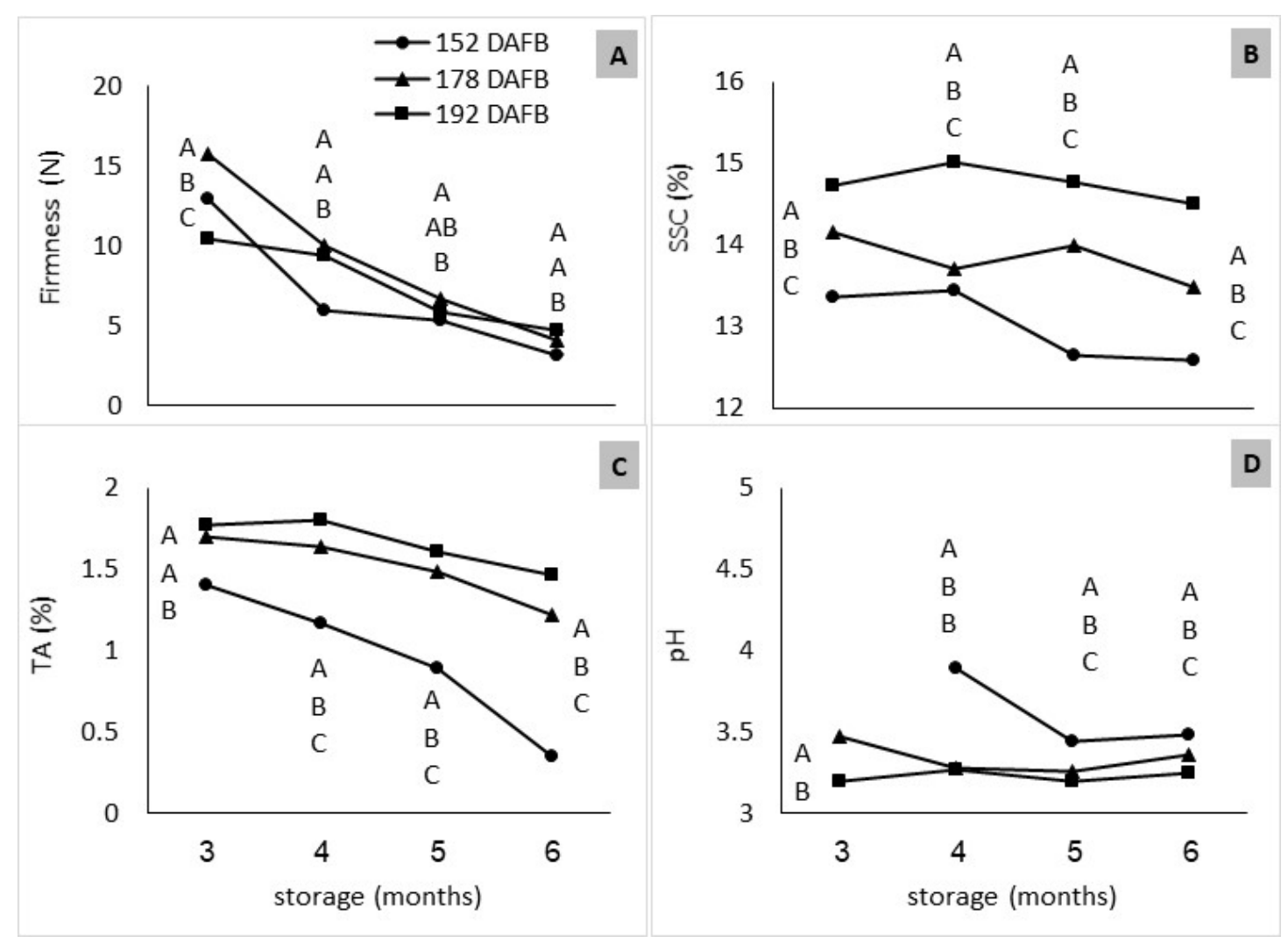

Figure 2. Effect of kiwifruit harvest time on changes in firmness (A), SSC (B), TA (C) and pH (D) during RA storage. The letters A-C represent significant differences at each month (Duncan $p<0.05$ ).

After three months' storage, the SSC content of fruit from all harvests reached the minimum value suitable for consumption- $12.5 \%$. However, late harvested kiwifruit, with the highest SSC at harvest, after six months' storage reached $14.5 \%$, compared to $12.6 \%$ in fruit harvested below $6 \%$ at 152 DAFB (Figure 2B).

Delaying harvest also slowed the rate of TA decline. After six months, the lowest TA content $(0.35 \%)$ was measured in fruit harvested at 152 DAFB and the highest $(1.46 \%)$ in 192 DAFB fruit (Figure 2C). $\mathrm{pH}$ values generally tended to change accordingly during storage, with the highest values attained in the early harvested fruit and the lowest in fruit from the last harvest (Figure 2D).

It is important to emphasize that fruit harvested at 178 DAFB and 192 DAFB had passed the threshold of acceptable maturity (6.5\% SSC). The late harvested fruit (192 DAFB), which had significantly higher contents of both SSC and TA than those of the middle harvest (178 DAFB), maintained these differences throughout storage and shelf life (Table 2). In addition, fruit of the latter harvests (178 and 192 DAFB) retained flesh firmness during storage better than earlier harvested fruit (152 DAFB). The 'overall taste index' showed a significant difference $(p<0.05)$ between 178 and 192 DAFB after shelf life, following six months' RA storage. That is, the organoleptic evaluation highlighted the benefit of a late harvest. 
Table 2. Ripening indices (mean \pm SE) of kiwifruit after shelf life, following six months of RA storage (2017) and eight months of CA storage with and without 1-MCP (2018).

\begin{tabular}{|c|c|c|c|c|c|c|}
\hline Harvest & 1-MCP & FTA (N) & SSC (\%) & TA (\%) & $\mathrm{pH}$ & Overall Taste Index \\
\hline \multicolumn{7}{|c|}{2017 RA storage, six months } \\
\hline 152 DAFB & - & $2.1 \pm 1.09 \mathrm{C}$ & $12.2 \pm 0.29 \mathrm{C}$ & $0.8 \pm 0.03 \mathrm{C}$ & $3.6 \pm 0.03 \mathrm{~A}$ & ND \\
\hline 178 DAFB & - & $2.9 \pm 1.33 \mathrm{~B}$ & $13.5 \pm 0.33 \mathrm{~B}$ & $1.1 \pm 0.04 \mathrm{~B}$ & $3.6 \pm 0.03 \mathrm{~A}$ & $3.6 \pm 2.38 \mathrm{~B}$ \\
\hline 192 DAFB & - & $3.3 \pm 1.33 \mathrm{~A}$ & $14.4 \pm 0.30 \mathrm{~A}$ & $1.4 \pm 0.03 \mathrm{~A}$ & $3.3 \pm 0.01 \mathrm{~B}$ & $8.8 \pm 1.92 \mathrm{~A}$ \\
\hline \multicolumn{7}{|c|}{2018 CA storage, eight months; 1-MCP [+]/no 1-MCP [-] } \\
\hline 192 DAFB & - & $6.9 \pm 0.36 \mathrm{~B}$ & $15.0 \pm 0.00$ & $1.4 \pm 0.02$ & $3.8 \pm 0.11$ & $4.0 \pm 1.2$ \\
\hline 202 DAFB & - & $7.7 \pm 0.44 \mathrm{~A}$ & $14.8 \pm 0.20$ & $1.5 \pm 0.03$ & $3.8 \pm 0.01$ & $3.2 \pm 1.6$ \\
\hline 192 DAFB & + & $9.1 \pm 0.40 \mathrm{~B}$ & $15.2 \pm 0.10$ & $1.6 \pm 0.02$ & $3.7 \pm 0.04$ & $3.5 \pm 0.9$ \\
\hline 202 DAFB & + & $10.0 \pm 1.02 \mathrm{~A}$ & $14.6 \pm 0.20$ & $1.6 \pm 0.05$ & $3.6 \pm 0.03$ & $2.9 \pm 1.1$ \\
\hline
\end{tabular}

The letters A-C represent significant differences $(p<0.05)$ between harvests, separately for each season.

\subsubsection{CA Storage}

During six months of CA storage in 2018, fruit firmness decreased significantly for all samples, from the initial values of 56-65 $\mathrm{N}$ at harvest to $11-16 \mathrm{~N}$ (Figure 3A). Although the two storage modes cannot be truly compared with fruit from different seasons, this value is more than double the firmness of fruit harvested at similar values in 2017 and stored for the same period in RA (Figure 2A). The decline in firmness continued with storage extension and after 10 months the values were similar to those of fruit stored for six months in RA in the previous year. However, delayed softening in RA, incurred by late harvest, was masked by inhibition of softening due to CA. Evidently the effects were not additive, as no significant differences between fruit from the two harvests were found in fruit firmness at any time during CA storage (Figure 3A), despite the significant difference at harvest (Table 2). However, the slower rate of softening of the late harvested fruit in storage compensated for the greater softness of the fruit at harvest, so that at the end of eight months' storage, the firmness of fruit from both harvests was almost identical, with a slight advantage for fruit of the late harvest. This slight difference became significant after a week of shelf life (Table 2). The application of 1-MCP before cold storage significantly delayed fruit softening during long-term storage and shelf life of fruit from both harvests and eliminated any difference between them.

In CA storage, with or without 1-MCP treatments, fruit attained SSC levels $>15 \%$ after six months' storage, which were maintained until 10 months. Throughout, SSC of fruit from the 202 DAFB harvest remained higher than that of 192 DAFB fruit, irrespective of 1-MCP treatment (Figure 3B), but there were no differences after shelf life (Table 2).

Delaying fruit harvest before $\mathrm{CA}$, slowed down the rate of TA decline in storage, as in RA stored fruit. Although the differences in TA levels in fruit from the two harvest dates were insignificant throughout storage, late-harvested fruit always had a higher TA content than early-harvested fruit, in both control and 1-MCP-treatment. Even after 10 months storage, fruit from both harvests maintained a relatively high TA content of $0.56-0.72 \%$. 1-MCP-treated fruit of the late harvest maintained an even higher TA content for up to eight months (Figure 3C). However, after 10 months there was no longer any difference between treatments. $\mathrm{pH}$ of juice from 192 DAFB and 202 DAFB fruit increased during storage to 4.8 and 4.2 respectively, without any effect of 1-MCP (Figure 3D). This reflects the slower decline in acidity of the late harvested fruit.

After eight months of CA storage fruit maintained a satisfactory overall taste, without significant differences between harvests (Table 2). 


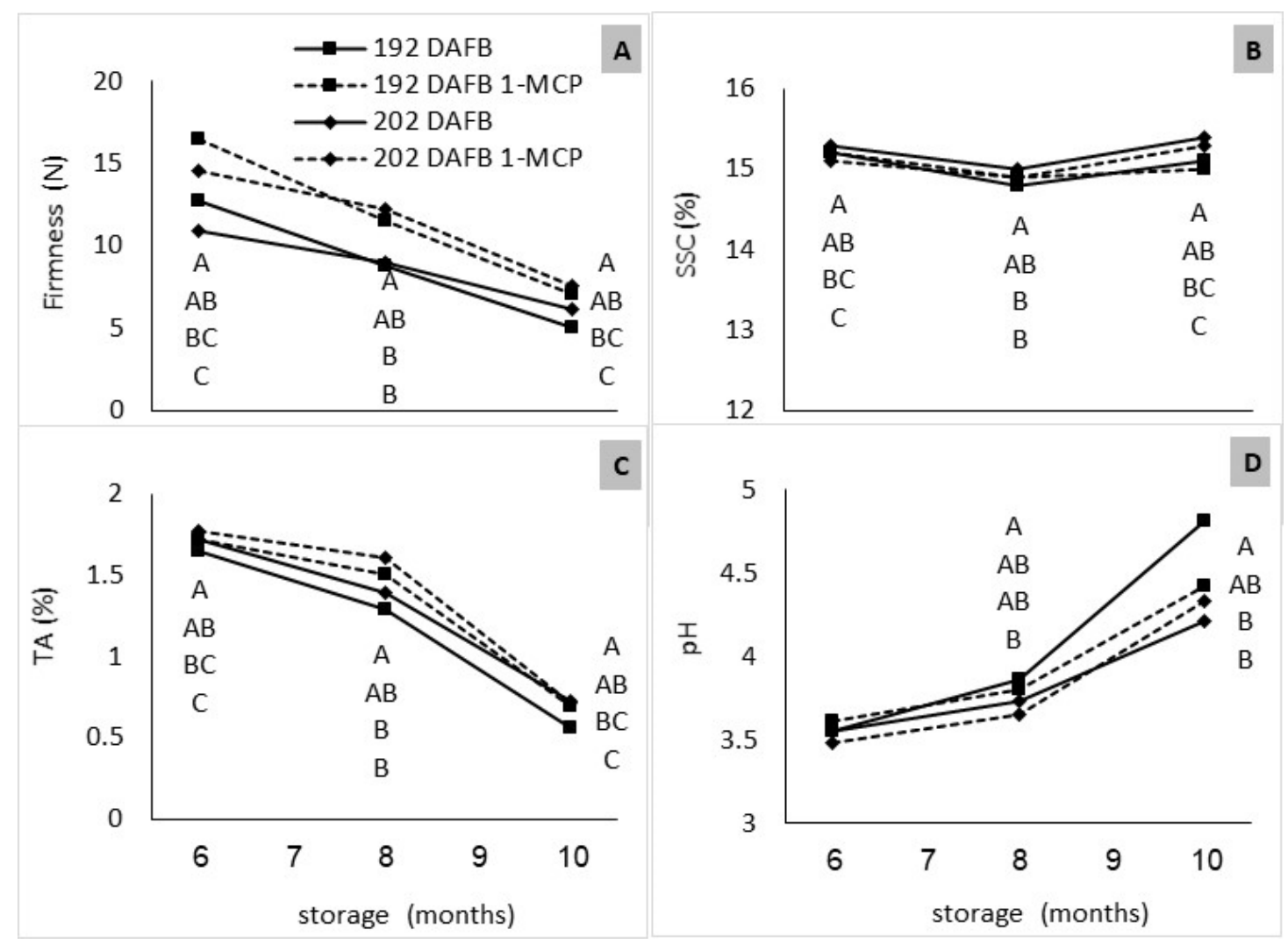

Figure 3. Effect of kiwifruit harvest time on changes in firmness (A), SSC (B), TA (C) and pH (D) during CA storage, with or without 1-MCP. The letters A-C represent significant differences at each month (Duncan $p<0.05)$.

\section{Discussion}

This work aimed at investigating changes in physicochemical properties of lateharvested kiwifruit (A. deliciosa, 'Hayward') during prolonged storage for six months in RA and 10 months in CA, with and without 1-MCP application prior to storage in CA. Determination of optimum harvesting maturity is crucial for prolonged kiwifruit storage and for eating quality. However, harvesting maturity may affect fruit storage life and postharvest quality characteristics contradictorily. On one hand, researchers observed a slower rate of softening in kiwifruit harvested at the early stages of maturity [3,28]. On the other, it was shown that late harvested fruit were firmer than early harvested fruit after storage $[13,19]$. Herein, a delay in harvest slowed down the overall rate of firmness loss, so that fruit of the latest harvest, which was the softest at harvest, had the slowest rate of softening during storage, irrespective of storage regime. As kiwifruit are often consumed with a relatively low SSC of 11-14\% [20], all results reported herein surpassed the minimal required level. As SSC increased at a similar rate in fruit from all harvests, the final levels achieved were in accordance with the initial harvest levels. In addition, a decline in the rate of TA loss in storage accompanied the delay in harvest. This is roughly in accordance with previous reports [29], showing that fruit harvested early in November, exhibited a greater loss of TA after RA storage than fruit harvested late in December. The higher levels of both SSC and TA in the late harvested fruit probably contributed to their superior taste after RA storage.

Kiwifruit ripening is unique amongst climacteric fruit with regard to ethylene biosynthesis, which is generally regarded as the ripening trigger, in that its firmness begins to decline much before the onset of ethylene autocatalytic production and the climacteric rise in respiration [30]. A typical softening curve of 'Hayward' [31] shows four distinct phases: gradual softening without ethylene evolution (Phase 1); rapid softening, initiation of ethylene production (Phase 2); autocatalytic ethylene production bringing the fruit to 
'eating ripe' (Phase 3); 'overripe', ethylene peak and decline (Phase 4). Kiwifruit, therefore, provide an excellent model system to gain an understanding of softening processes that are independent of endogenous ethylene production, as has been demonstrated with low temperature modulated ripening of 'Sanuki Gold' kiwifruit (30). With this cultivar, significant fruit softening, accumulation of mRNA for polygalacturonase (PG), pectin lyase (PL) and expansin, as well as decreased TA, were observed without ethylene production in intact fruit stored for one month at a low temperature.

Unlike softening, the decline in acidity, another aspect of fruit ripening, does not precede the onset of ethylene production in kiwifruit [32]. During fruit ripening there can be either a net dissimilation or synthesis of stored Krebs cycle acids, and which pathway occurs depends on the fruit [33]. Although the function of this turnover is uncertain, it could be associated with $\mathrm{pH}$ regulation. A characteristic feature of the organic acids in kiwifruit is that their concentration increases until the fruit begin to ripen and then decreases. In addition, kiwifruit have high concentrations of organic acids compared to many climacteric fruit, contributing $1 \%$ to $3 \%$ of fresh weight [34]. This continuous acid accumulation may indicate that, at the first two harvests, the fruit was not yet fully mature. We show that the high TA level maintained a low $\mathrm{pH}$ environment in the softening fruit tissue. The maintenance of high acidity until the onset of the exponential increase in ethylene is supported by the suggested regulatory role of iso-citrate dehydrogenase in the respiratory climacteric [35]. In apples, it has been shown by inactivating ethylene with 1-MCP that ethylene is involved in the regulation of the levels of malate and citrate [36].

Softening of kiwifruit involves the depolymerization of xyloglucan and pectin by at least five enzymes: $\beta$-galactosidase $(\beta \mathrm{Gal})$, xyloglucan endohydrolase $(\mathrm{XEH})$, xyloglucan endotransglucosylase (XET), pectin methylesterase (PME), and polygalacturonase (PG) [37]. This is a very complex process, not fully understood, wherein these enzymes probably act both in tandem and sequentially [38-40]. We postulate that their activity is controlled, at least partially, by the apoplastic $\mathrm{pH}$. Interestingly, if we arrange the above five enzymes in order of their optimum $\mathrm{pH}$ for activity, we find the following sequence: PME (4.5) [41], $\beta$ Gal (4.9) [42], XEH (5.5) [43], XET (5.8) [44], and PG (5.5) [45]. This appears to be quite a logical sequence for cell wall disassembly and is supported by reports in the literature that PME activity declines as fruit ripen becoming very inactive in fully ripe fruit, whereas PG activity is the opposite [45,46]. XEH activity was also not detected in firm fruit, but increased with softening [37] and its hydrolytic activity at a lower $\mathrm{pH}$ and prior to its trans-glycolytic activity is logical. Therefore, the reduced rate of softening in late harvested kiwifruit might be due to the high TA level maintained in the fruit until the onset of autocatalytic ethylene production. This, in turn, promotes a decline in acidity and an increase in $\mathrm{pH}$, thus enabling the gradual increase in the activities of the cell wall degrading enzymes involved in the later phases of kiwifruit softening.

\section{Conclusions}

Delaying the harvest of 'Hayward' kiwifruit prior to RA or CA storage under optimal conditions, was an advantage from both the physiological and organoleptic points of view, enabling six and 10 months of storage, respectively. The optimal conditions are those that mitigate the potential for decay development, which increases with the delay in harvest. From a commercial aspect the rule should therefore be 'Last in, last out' (LILO).

Author Contributions: Conceptualization, T.G., H.A. and R.B.-A.; visualization, T.G. and H.A.; investigation, T.G.; writing-original draft, T.G.; formal analysis, H.A.; methodology, R.B.-A.; writing-review and editing, R.B.-A. All authors have read and agreed to the published version of the manuscript.

Funding: This research received no external funding.

Institutional Review Board Statement: Not applicable.

Informed Consent Statement: Not applicable. 
Data Availability Statement: The datasets generated during and/or analyzed during the current study are available from the corresponding author on request.

Acknowledgments: We wish to thank the board of Israeli kiwifruit growers for their financial support. We are grateful to Alla Zviling, Hiba Ibrahim, and Ronen Shafir for technical assistance and to Susan Lurie for her valuable comments.

Conflicts of Interest: The authors declare no conflict of interest.

\section{References}

1. Sfakiotakis, E.; Antunes, M.; Stavroulakis, G.; Niklis, N. Ethylene Biosynthesis. Its Role in Ripening and Quality of 'Hayward' Kiwifruit after Harvest, during Storage and Shelf Life. In Crop Management and Postharvest Handling of Horticultural Products; Oxford \& IBH Publishing Co. Pvt. Ltd.: New Delhi, India, 2001; Volume 1.

2. Goldberg, T.; Agra, H.; Ben-Arie, R. Non-destructive measurement of fruit firmness to predict the shelf-life of 'Hayward' kiwifruit. Sci. Hortic. 2019, 244, 339-342. [CrossRef]

3. Macrae, E.A.; Lallu, N.; Searle, A.N.; Bowen, J.H. Changes in the softening and composition of kiwifruit (Actinidia deliciosa) affected by maturity at harvest and postharvest treatments. J. Sci. Food Agric. 1989, 49, 413-430. [CrossRef]

4. Burdon, J.; Pidakala, P.; Martin, P.; Billing, D.; Boldingh, H. Fruit maturation and the soluble solids harvest index for 'Hayward' kiwifruit. Sci. Hortic. 2016, 213, 193-198. [CrossRef]

5. Choi, H.; Tilahun, S.; Park, D.; Lee, Y.; Choi, J.; Baek, M.; Jeong, C. Harvest time affects quality and storability of kiwifruit (Actinidia spp.) cultivars during long-term cool storage. Sci. Hortic. 2019, 256, 108523. [CrossRef]

6. Crisosto, G.U.; Mitchell, F.G.; Arpaia, M.L.; Mayer, G. The effect of growing location and harvest maturity on the storage performance and quality of 'Hayward' kiwifruit [California]. J. Am. Soc. Hortic. Sci. 1984, 109, 584-587.

7. Harman, J.E. Kiwifruit maturity [New Zealand]. Orchard. N. Z. 1981, 54, 126-127.

8. Burdon, J.; Lallu, N.; Pidakala, P.; Barnett, A. Soluble solids accumulation and postharvest performance of 'Hayward' kiwifruit. Postharvest Biol. Technol. 2013, 80, 1-8. [CrossRef]

9. Burdon, J. Subtropical fruits: Kiwifruit. In Controlled and Modified Atmospheres for Fresh and Fresh-Cut Produce, 1st ed.; Gil, M.I., Beaudry, R., Eds.; Academic Press: Cambridge, UK, 2020; pp. 447-454.

10. Meena, N.; Baghel, M.; Jain, S.K.; Asrey, R. Postharvest biology and technology of kiwifruit. In Postharvest Biology and Technology of Temperate Fruits; Mir, S., Shah, M., Mir, M., Eds.; Springer International Publishing: New York, NY, USA, 2018 ; pp. $299-329$.

11. Gwanpua, S.G.; Jabbar, A.; Zhao, M.; Heyes, J.A.; East, A.R. Investigating the potential of dual temperature storage as a postharvest management practice to mitigate chilling injury in kiwifruit. Int. J. Refrig. 2018, 86, 62-72. [CrossRef]

12. Maguire, K.M.; Amos, N.; Kelly, D. Influence of storage temperature and at-harvest maturity on incidence of chill-related disorders in 'Hort16a' kiwifruit. Acta Hort. 2004, 687, 57-62. [CrossRef]

13. Costa, G.; Quadretti, R.; Succi, A.; Morigi, M. Influence of harvest time and temperature on fruit quality and storage of kiwifruit (cv Hayward). Acta Hort. 1997, 444, 517-522. [CrossRef]

14. Famiani, F.; Baldicchi, A.; Farinelli, D.; Cruz-Castillo, J.G.; Marocchi, F.; Mastroleo, M.; Moscatello, S.; Proietti, S.; Battistelli, A. Yield affects qualitative kiwifruit characteristics and dry matter content may be an indicator of both quality and storability. Sci. Hortic. 2012, 146, 124-130. [CrossRef]

15. Matsumoto, S.; Obara, T.; Luh, B.S. Changes in chemical constituents of kiwifruit during post-harvest ripening. J. Food Sci. 1983, 48, 607-611. [CrossRef]

16. Wang, M.; Macrae, E.; Wohlers, M.; Marsh, K. Changes in volatile production and sensory quality of kiwifruit during fruit maturation in Actinidia deliciosa 'Hayward' and A. chinensis 'Hort16A'. Postharvest Biol. Technol. 2011, 59, 16-24. [CrossRef]

17. Nishiyama, I.; Fukuda, T.; Shimohashi, A.; Oota, T. Sugar and organic acid composition in the fruit juice of different Actinidia varieties. Food Sci. Technol. Res. 2008, 14, 67-73. [CrossRef]

18. Burdon, J.; McLeod, D.; Lallu, N.; Gamble, J.; Petley, M.; Gunson, A. Consumer evaluation of 'Hayward' kiwifruit of different at-harvest dry matter contents. Postharvest Biol. Technol. 2004, 34, 245-255. [CrossRef]

19. Mitchell, F.G.; Mayer, G.; Biasi, W. Effect of harvest maturity on storage performance of 'Hayward' kiwifruit. Acta Hort. 1992, 297, 617-626. [CrossRef]

20. Asiche, W.O.; Gituma, M.E.; Oda, C.; Witere, M.O.; Omondi, O.W.; Ushijima, K.; Nakano, R.; Kubo, Y. Extension of shelf-life by limited duration of propylene and 1-MCP treatments in three kiwifruit cultivars. Hort. J. 2016, 85, 76-85. [CrossRef]

21. Burdon, J.; Pidakala, P.; Martin, P.; Billing, D. Softening of 'Hayward' kiwifruit on the vine and in storage: The effects of temperature. Sci. Hortic. 2017, 220, 176-182. [CrossRef]

22. Given, N.K. Kiwifruit. In Biochemistry of Fruit Ripening; Seymour, G.B., Taylor, J.E., Tucker, G.A., Eds.; Springer: Dordrecht, The Netherlands, 1993; pp. 235-254.

23. Koukounaras, A.; Sfakiotakis, E. Effect of 1-MCP prestorage treatment on ethylene and $\mathrm{CO}_{2}$ production and quality of 'Hayward' kiwifruit during shelf-life after short, medium and long term cold storage. Postharvest Biol. Technol. 2007, 46, 174-180. [CrossRef]

24. Crisosto, C.H.; Kader, A.A. Kiwifruit postharvest quality maintenance guidelines. Cent. Val. Post Harvest. Newsl. 1999, 8, 1-11.

25. Gullo, G.; Dattola, A.; Liguori, G.; Vonella, V.; Zappia, R.; Inglese, P. Evaluation of fruit quality and antioxidant activity of kiwifruit during ripening and after storage. J. Berry Res. 2016, 6, 25-35. [CrossRef] 
26. Burdon, J. Soluble solids revisited: A maturity or harvest index for Kiwifruit. Acta Hort. 2015, 1096, 257-266. [CrossRef]

27. Burdon, J.; Pidakala, P.; Martin, P.; McAtee, P.A.; Boldingh, H.L.; Hall, A.; Schaffer, R.J. Postharvest performance of the yellowfleshed 'Hort16A' kiwifruit in relation to fruit maturation. Postharvest Biol. Technol. 2014, 92, 98-106. [CrossRef]

28. Tavarini, S.; Degl'Innocenti, E.; Remorini, D.; Massai, R.; Guidi, L. Polygalacturonase and $\beta$-galactosidase activities in 'Hayward' kiwifruit as affected by light exposure, maturity stage and storage time. Sci. Hortic. 2009, 120, 342-347. [CrossRef]

29. Ferrandino, A.; Guidoni, S. Chemical composition of Actinidia deliciosa fruits as influenced by harvest date and storage period. Acta Hort. 1999, 498, 313-318. [CrossRef]

30. Kim, H.O.; Hewett, E.W.; Lallu, N. The role of ethylene in kiwifruit softening. Acta Hort. 1999, 498, 255-262. [CrossRef]

31. Atkinson, R.G.; Gunaseelan, K.; Wang, M.Y.; Luo, L.; Wang, T.; Norling, C.L.; Johnston, S.L.; Maddumage, R.; Schroder, R.; Schaffer, R.J. Dissecting the role of climacteric ethylene in kiwifruit (Actinidia chinensis) ripening using a 1-aminocyclopropane-1-carboxylic acid oxidase knockdown line. J. Exp. Bot. 2011, 62, 3821-3835. [CrossRef]

32. Mworia, E.G.; Yoshikawa, T.; Salikon, N.; Oda, C.; Asiche, W.O.; Yokotani, N.; Abe, D.; Ushijima, K.; Nakano, R.; Kubo, Y. Low-temperature-modulated fruit ripening is independent of ethylene in 'Sanuki Gold' kiwifruit. J. Exp. Bot. 2012, 63, 963-971. [CrossRef]

33. Famiani, F.; Battistelli, A.; Moscatello, S.; Cruz-Castillo, J.G.; Walker, R. The organic acids that are accumulated in the flesh of fruits: Occurrence, metabolism and factors a ffecting their contents. Rev. Chapingo. Ser. Hortic. 2015, 21, 97-128. [CrossRef]

34. Marsh, K.; Harker, F. Acid metabolism in kiwifruit. In The Kiwifruit Genome; Testolin, R., Huang, H.W., Ferguson, A., Eds.; Springer: Cham, Switzerland, 2016; pp. 179-188.

35. Gamrasni, D.; Erov, M.; Saar, L.; Raz, A.; Glikman, M.; Sonawane, P.D.; Aharoni, A.; Goldway, M. The isocitrate dehydrogenase 1 gene is associated with the climacteric response in tomato fruit ripening. Postharvest Biol. Technol. 2020, 166, 111219. [CrossRef]

36. Lu, X.; Nock, J.F.; Ma, Y.; Liu, X.; Watkins, C.B. Effects of repeated 1-methylcyclopropene (1-MCP) treatments on ripening and superficial scald of 'Cortland' and 'Delicious' apples. Postharvest Biol. Technol. 2013, 78, 48-54. [CrossRef]

37. Fullerton, C.G. Kiwifruit Softening: A Cell Wall Study. Ph.D. Thesis, University of Auckland, Auckland, New Zealand, 2015.

38. Gapper, N.E.; McQuinn, R.P.; Giovannoni, J.J. Molecular and genetic regulation of fruit ripening. Plant Mol. Biol. 2013 , 82, 575-591. [CrossRef] [PubMed]

39. Goulao, L.; Oliveira, C. Cell wall modifications during fruit ripening: When a fruit is not the fruit. Trends Food Sci. Technol. 2008, 19, 4-25. [CrossRef]

40. Posé, S.; Paniagua, C.; Matas, A.J.; Gunning, A.P.; Morris, V.J.; Quesada, M.A.; Mercado, J.A. A nanostructural view of the cell wall disassembly process during fruit ripening and postharvest storage by atomic force microscopy. Trends Food Sci. Technol. 2019, 87, 47-58. [CrossRef]

41. Jakób, A.; Bryjak, J.; Polakovič, M. Selection of a method for determination of activity of pectinolytic enzymes in berry fruit materials. Chem. Pap. 2009, 63, 677. [CrossRef]

42. Ross, G.S.; Redgwell, R.J.; MacRae, E.A. Kiwifruit $\beta$-galactosidase: Isolation and activity against specific fruit cell-wall polysaccharides. Planta 1993, 189, 499-506. [CrossRef]

43. Morales-Quintana, L.; Beltrán, D.; Mendez-Yañez, Á.; Valenzuela-Riffo, F.; Herrera, R.; Moya-León, A.M. Characterization of FcXTH2, a Novel Xyloglucan Endotransglycosylase/Hydrolase Enzyme of Chilean Strawberry with Hydrolase Activity. Int. J. Mol. Sci. 2020, 21, 3380. [CrossRef]

44. Schroder, R.; Atkinson, R.G.; Langenkamper, G.; Redgwell, R.J. Biochemical and molecular characterisation of xyloglucan endotransglycosylase from ripe kiwifruit. Planta 1998, 204, 242-251. [CrossRef]

45. Bonghi, C.; Pagni, S.; Vidrih, R.; Ramina, A.; Tonutti, P. Cell wall hydrolases and amylase in kiwifruit softening. Postharvest Biol. Technol. 1996, 9, 19-29. [CrossRef]

46. Soda, I.; Hasegawa, T.; Suzuki, T.; Ogura, N. Detection of polygalacturonase in kiwifruit during ripening. Agric. Biol. Chem. 1986, 50, 3191-3192. 